\title{
REPRESENTASI BANGSAWAN SASAK DALAM TEKS ANGIN ALUS MASYARAKAT SASAK
}

\author{
Dharma Satrya HD dan Zainul Muttaqin \\ Universitas Hamzanwadi Lombok \\ email: dharmasatryahd@gmail.com
}

\begin{abstract}
Abstrak
Penelitian ini bertujuan mendeskripsikan representasi bangsawan Sasak dalam teks Angin Alus masyarakat Sasak-Lombok. Pembahasan teks ini menggunakan perspektif semiotik Peirce dengan metode analisis Recouer. Pembahasan terdiri atas analisis struktur teks dan dunia yang digelar teks dan analisis hubungan pertama dan kedua dengan dunia penafsir. Hasil penelitian menemukan bahwa teks Angin Alus menunjukkan representasi kabar kesedihan orang Sasak dan bangsawan karena kehidupan membawanya ke suatu ruang yang memberikan penderitaan, baik dalam konteks historis Sasak maupun dalam konteks kekinian dengan konteks sosial yang berbeda. Hal tersebut mengindikasikan bahwa masyarakat Sasak juga mengalami percampuran dengan pihak luar yang mempengaruhi caranya memandang kehidupan. Generari muda Sasak-Lombok harus memahami posisi sebagai buaq ate, kembang mate, generasi yang selalu berserah diri dan sebagai lomboq, dengan selalu mengembalikannya kepada yang satu ( $\mathrm{Sa} S a k$ ), yakni Tuhan. Perbedaan antara diri dan yang lain melebur menjadi Sasak-Lombok sekarang.
\end{abstract}

Kata kunci: representasi, masyarakat Sasak, kabar kesedihan, bangsawan

\section{THE REPRESENTATION OF SASAK ARISTOCRATS IN SASAK COMMUNITY'S TEXT ANGIN ALUS}

\begin{abstract}
This study aims to describe the representation of Sasak aristocrats in Sasak-Lombok community's text Angin Alus. The discussion of the text used Peirce's semiotic perspective and Recouer's analysis method. It consisted of the analysis of the text structure and the world represented by the text and the analysis of the first and second relationships with the world of interpreters. The research finding reveals that the text Angin Alus shows the representation of the news of sadness of Sasak people and aristocrats because life brings them to a space that gives suffering, both in the historical context of Sasak and in the contemporary context with different social contexts. This indicates that Sasak community also experience mixing with outsiders that affect the way they view life. Sasak-Lombok young generation have to understand the positions as buaq ate and kembang mate, as a generation that always show submission and as lomboq by always returning it to the one ( $S a S a k$ ), namely God. The differences between the self and others merge into the present Sasak-Lombok.
\end{abstract}

Keywords: representation, Sasak community, Angin Alus, news of sadness, aristocrats 


\section{PENDAHULUAN}

Teks angin alus merupakan karya para pendahulu masyarakat Sasak. Tidak diketahui siapa penulis tembang itu. Namun, ia selalu hadir dan dihadirkan oleh masyarakat. Kehadirannya dalam konteks masa lalu berbeda dengan kehadirannya dalam konteks masa kini. Dalam konteks masa lalu ia hadir sebagai produk yang murni kelisanan, sedangkan dalam konteks kekinian ia hadir sebagai produk budaya popular. Permasalahannya, kenapa teks itu selalu dihadirkan? Merepresentasikan apa teks tersebut? Permasalahan tersebut dijawab dengan pendekatan semiotik model Peirce dengan metode analisis interpretasi Paul Recoeur. Pemaknaan terhadap teks tersebut dipahami dalam kerangka komunikasi. Pada tahap pertama tanda tersebut tidak berarti apa-apa sampai tanda tersebut berhubungan dengan objek (Noth, 1995: 41). Hubungan antara yang pertama dan kedua tersebut hanya berarti dalam hubungannya dengan yang ketiga yaitu interpreter (Noth, 1995: 41). Yang pertama menjadi dasar untuk interpreter memaknai objek tersebut. Dalam penelitian ini, tanda tersebut adalah teks angin alus dan objeknya adalah masyarakat Sasak, sedangkan interpreternya adalah peneliti. Representasi dengan model semiotik tersebut mengasumsikan bahwa teks angin alus merepresentasikan orang Sasak bangsawan.

Penelitian tentang representasi Sasak pernah dilakukan oleh Fauzan (2013). Dalam penelitian itu, Fauzan (2013: 254) menemukan bahwa masyarakat Sasak berasal perwujudan jin perwangsa menjadi manusia Sasak yang kemudian membentuk kerajaan awal Sasak. Masyarakat Sasak menurutnya mengidealkan posisi pusat, pusat anutan, sehingga dalam cerita
Doyan Neda ia menemukan bahwa SasakLombok mengidealkan posisi pusat anutan, yaitu Majapahit. Hal itu dibuktikan dengan menikahnya raja Seleparang dengan anak Raja Majapahit. Penelitian Fauzan menunjukkan bahwa representasi Sasak dalam perspektif struktural. Sedangkan, representasi Sasak Lombok dalam teks yang sama diteliti oleh Usup (2011). Usup menemukan bahwa masyarakat Sasak sangat plural dan religious. Pluralitas tersebut ditunjukkan menikahnya raja-raja di Lombok dengan putri raja dari Madura dan Jawa, serta tersebarnya pusat-pusat Islam. Penelitian Usup tersebut lebih melihat teks Doyan Neda dalam perpektif pascastruktural. Penelitian yang lebih mendalam dilakukan oleh Fajri (2015) dengan perspektif pascakolonial. Fajri (2015: 396) menemukan bahwa terdapat dua kategori kelas dalam masyarakat Sasak, yaitu bangsawan kawula dan perwangsa dengan jamaq. Menurut Fajri, perwangsa dengan jamaq inilah yang merupakan representasi orang Sasak, sedangkan bangsawan kawula merupakan representasi Jawa. Tetapi karena bangsawan kawula ini dekat dengan kekuasaan terutama pada masa kolonial maka dialah yang direpresentasikan oleh kolonial pada masa itu yang jejaknya masih tersisa sampai sekarang, seperti dalam teks angin alus. Penelitian ini membuktikan tesis Fajri tersebut. Teks angin alus merepresentasikan bangsawan. Hal itu dapat dibuktikan dengan penggunakan bahasa dalam teks tersebut. Tanda yang menunjukkan hal tersebut adalah mas mirah dan dende. Istilah mas mirah digunakan Jawa untuk menyebut sasak yang tertuang dalam kitab Negara Kertagama. Istilah denda adalah istilah yang digunakan untuk menyebut perempuan bangswan. Sasak-Lom- 
bok tidaklah mengenal istilah kebangsawanan (Fajri, 2015: 397). Sejak awal penciptaannya berdasarkan teks Doyan Neda Sasak-Lombok adalah penjelmaan jin perwangsa (Fauzan, 2013: 254).

Realitas masyarakat Sasak dalam perspektif ilmu sejarah menunjukkan realitas Sasak yang bermacam-macam berdasarkan perspektif melihat realitas, misalnya Fauzan dengan perspektif struktural, Usup dengan perspektif pascastruktural, dan Fadjri dengan perspektif pascakolonial. Namun, realitas sasak terus didefinisikan dalam konteks yang berbeda. Trisnawati (2016) menunjukkan masyarakat Sasak yang harmonis dalam beragamnya etnis yang mendiami pulau Lombok. Kesenian Sasak bercampur dengan kesenian modern (Yudarta \& Pasek, 2017). Keberadaan kesenian Bali mendukung pariwisata di Kota Mataram (Yudarta, 2016). Dalam konteks demikian, teks angin alus tetap hadir dan dihadirkan oleh masyarakat Sasak. Kehadiran teks angin alus perlu didialogkan dengan realitas yang dikonstruksi oleh hasil penelitian-penelitian tersebut.

\section{METODE}

Metode penelitian ini menggunakan interpretasi. Teks angin alus ini sebagai produk budaya lisan dan popular. Data diperoleh melalui media, yaitu dilisankan dan dimultimediakan. Metode analisis data menggunakan metode interpretasi, yaitu model hermeneutika-fenomenologis. Teks angin alus sebagai fakta semiotik. Fakta semiotik di dalam teks bukan peristiwa yang terkandung di dalam teks, tetapi interpretasinya (Faruk, 2012: 101). Interpretasi itu mengkristal dalam empat kategori, yaitu objektivasi melalui struktur, distansiasi, dunia teks dan aproprasi (Har- yatmoko, 2015: 81). Analisis terhadap kata, frasa, dan kalimat berhubungan dengan empat kategori tersebut yang kemudian menjadi langkah dalam analisis.

Teks angin alus diperoleh melalui sumber lisan dan media. Data teks yang diperoleh dari sumber lisan dipadukan dengan data teks dalam media (lagu). Data teks dianalisis dengan interpretasi berdasarkan pengalaman atau kesadaran penafsir (peneliti) sebagai orang Sasak. Metode interpretasi bersifat terbuka sehingga tidak dibatasi oleh maksud pengarang. Pertama, analisis struktur teks, yaitu hubungan antara teks angin alus dengan masyarakat Sasak. Kedua, analisis dunia yang digelar teks. Dunia yang digelar teks diperoleh melalui struktur teks. Struktur teks mengarahkan pemaknaan. Ketiga, struktur teks dan arah pemaknaan menjadi milik penafsir. Pada tahap ini struktur teks dan pemaknaan diarahkan atau didialogkan dengan dunia kongkret penafsir.

\section{HASIL DAN PEMBAHASAN \\ Dunia Teks, Kabar Luka dan Kesedihan}

Teks tembang angin alus terdiri dari dua bait. Bait pertama merepresentasikan rasa kehilanagan, luka, kerelaan, dan harapan orang Sasak pada sosok anak. Bait pertama, yaitu Aduh anakku mas mirah, buaq ate kembang mate, mulen tulen kubantelin, sintung jari salon angin. Frase angin alus, yang dijadikan judul dalam teks itu, secara qualisign memiliki sifat halus dan lembut. Judul itu mengandung pengertian angin yang halus. Sebagai sesuatu yang halus jika dikembalikan dalam kehidupan dan diri manusia adalah nafas, yang tampil nyata dalam hidup. Angin alus adalah metafor dari suara hati yang paling dalam. Alus adalah kondisi nafas yang keluar 
masuk dan angin adalah unsur hidup yang menghidupi seluruh tubuh, karena hidup itu bernafas, keluar masuknya angin. Dengan demikian, angin menjadi ikon dari hidup, yang memiliki kehidupan, dan bahkan cara hidup itu dijalani. Hidup dioposisikan dengan mati, sedangkan alus beroposisi dengan keras. Halus (alus) dan keras adalah sebuah kondisi hidup seseorang, apakah dengan nafas yang alus atau keras. Menurut Nuriadi (2014), masyarakat Sasak mempunyai karakter keras dan praktis. Dalam teks itu yang muncul adalah kondisi alus yang artinya berada dalam kondisi tenang. Artinya, teks itu menggambarkan kehidupan yang halus atau lembut, bukan keras dan praktis sebagaimana dikemukakan Nuriadi. Yang penting adalah bahwa angin menjadi simbol kehidupan, simbol kehidupan yang masih berjalan. Kehidupan yang keras dan halus tentunya hadir bersamaan. Namun, bagaimana perjalanannya dapat dilihat pada bait-bait dalam teks tersebut. Jika itu merupakan simbol kehidupan, maka kehidupan siapa dan seperti apa yang sedang ditunjukkan oleh teks tersebut?

Kata aduh merupakan kata seruan yang secara implisit menjadi qualisign terhadap kedirian orang (tua) Sasak. Aduh adalah ungkapat rasa sakit, juga penyesalan atas yang sudah terjadi. Dalam bait itu, aduh bukanlah rasa sakit tetapi sebuah ungkapan prihatin yang ditunjukkan untuk generasi penerus atau anaknya. Ungkapan rasa sakit atau kehilangan dan luka tidak hanya terjadi pada masa kini, tetapi dirasakan sepanjang sejarah hidup masyarakat. Masyarakat Sasak mengalami penjajahan oleh Jawa, Bali, Belanda, dan Jepang (Kingsley, 2011: 98; Budiwanti, 2000). Masyarakat mengalami penaklukan oleh Oleh
Karangasem Bali (Kraan, 2009: 8). Penaklukan tersebut, menurut Hagerdal (2016) bukanlah penaklukan Bali, tetapi kolonial, karena menurutnya Bali adalah orang kepercayaan kolonial di Lombok. Hal itulah yang membuat masyarakat Lombok mengalami luka atau kesedihan yang berkepanjangan sejak abad 17, yang menurut Fadjri (2015) terjadi sampai rezim Orde Baru.

Kata aduh merupakan sinsign verbal ketika polemik yang terjadi dalam tahap batin harus diutarakan. Aduh menandai apa yang dirasakan. Adapun frasa aduh anakku bersifat indeksikal yang menandai adanya kausalitas bahwa orang tua dan anak saling merefleksikan, hubungan pencerminan, anak menjadi cermin orang tua. Baik dan tidaknya seorang anak akan tampak dari orang tuanya. Sehingga secara simbolis bisa dilihat bahwa anak menjadi symbol orang tua. Pada tatanan dicent frasa aduh anakku kemudian menjadi proyeksi bagaimana sosok orang tua Sasak menjaga dan mencintai anak atau generasi penerusnya. Hal ini sejalan dengan klausa buaq ate kembang mate (buah hati) itu sendiri. Sehingga, tidak heran kemudian orang tua Sasak terkadang menyebut atau memanggil sang anak dengan panggilan kasta seperti dende. Penggunaan kata denda menempatkan teks itu dalam ideologi bangsawan. Fauzan (2013) menunjukkan masyarakat Sasak mengidealkan posisi anutan, yaitu Jawa Majapahit yang dimitoskan dalam mitologi asal-usul orang Sasak.

Selanjutnya frasa mas mirah merupakan sinsign bagi masyarakat Sasak dalam penyebutan anak. Kata mirah sendiri bermakna permata, secara qualisign berarti sesuatu yang dianggap paling berharga yang dimiliki orang tua. Hubungan anak dan orang tua terlihat di dalam bentuk 
perhatian. Orang tua memberikan hati dan perhatiannya untuk anakanya. Hubungan keduanya berada dalam hubungan antara yang memberi dan menerima, hubungan kasih sayang, hubungan antara asal dan tujuan. Orang tua menjadi reprsentasi tuhan oleh karena itu apapun yang terjadi atau menimpa anaknya dan apapun yang dilakukan anaknya, baik itu melanggar tatanan atau tidak kasih orang tua tidak berada dalam hukum kausalitas, karena orang tua selalu akan memberikan kasih sayangnya kepada anak. Mirah menjadi ikonitas bagi masyarakat Sasak yang lomboq lempeng (lurus, baik) karena kejujuran dan apa adanya orang Sasak inilah yang kemudian menjadi mutiara yang berharga. Hal tersebut dipertegas dalam kitab Negara kertagama yang ditulis oleh empu prapanca yaitu Lombok mirah sasak adi (kejujuran adalah permata yang utama) (Fauzan, 2013). Istilah mas mirah adalah istilah yang digunakan orang Jawa untuk menyebut Sasak-Lombok. Jawa menyebut orang Sasak jujur dan kejujuran itu adalah permata. Kejujuran diidentitaskan dalam konteks membayar upeti ke kolonial. Namun kejujuran itu bukanlah sebuah kejujuran, tetapi sebuah ketakutan. Kolonial mengkonstruksi Sasak sebagai orang yang bermental terjajah (Fajri, 2015: 395).

Fajri (2015: 400-1) menjelaskan bahwa penjajahan yang terjadi di Lombok disebabkan oleh bekerjasamanya pihak luar Sasak, Jawa dan Bali. Pada masa kolonial mereka mendapat posisi penting dalam pemerintahan. Dengan demikian, mas mirah menjadi nama yang dilekatkan pihak luar untuk menyebut Sasak. Orang Sasak memahami Lombok sebagai lombok, yang artinya lurus yang tidak sama dengan jujur. Lomboq mengacu pada keyakinan yang satu. Namun, bagaimana keyakinan pada yang satu tidaklah sesederhana kayakinan dalam pengertian islam Arab. Itulah yang sebenarnya permata itu dalam pengertian orang Sasak. Dalam konteks bait di atas, anak adalah permata orang tua, permata yang diberikan Tuhan kepadanya. Oleh karena itu, mirah menjadi simbol penghargaan, menjadi simbol harga diri orang Sasak. Mas mirah adalah simbolisasi dari betapa berharganya darah dagingnya, yaitu anak. Baris aduh anakku mas mirah kemudian mereprerentasikan rasa harap, cinta dan ketakutan orang tua kepada sesuatu yang paling berharga (mirah) yaitu anak.

Baris kedua yaitu buaq ate kembang mate. Frasa buaq ate merupakan ungkapan metaforis untuk merujuk pada susuatu yang berharga. Kata buaq sendiri bermakna buah yang secara semantik merupakan hasil dari proses pembuahan pada tumbuhan. Pada tataran rhema, kata buaq adalah identitas Sasak itu sendiri. Kata buaq juga menjadi ikonitas yang dilekatkan dengan kebiasaan orang Sasak yang mamaq (memakan sirih dan buah pinang). Jika pada zaman dahulu ketika orang Sasak bertamu selalu disuguhkan penginang yang berisi buaq, apur, dan sirih sebagai ungkapan selamat atas kedatangan atau kunjungan kerabat dan saudara mereka. Sementara itu, ate dalam bahasa Indonesia berarti hati yang menjadi sumber penentu dalam kehidupan manusia. Hati kemudian menjadi ikonitas pemiliknya. Jika hatinya baik, maka baik pula sikap dan prilaku yang dimunculkan oleh sang pemilik hati tersebut. Hati pada dasarnya memiliki peran sentral dalam diri manusia, karena hati menjadi penentu. Kata ate (hati) dan buaq sama-sama memiliki urgensitas yang cukup kuat. Oleh sebab itu, kemudian kedua kata tersebut 
bersifat indeksikal bagi orang Sasak untuk mengungkapkan sesuatu yang paling berharga. Frase buaq ate (buah hati) mengacu pada anak kesayangan yang tampil dalam kenyataan sebagai kasih sayang yang berlebihan sebagaimana dulu orang tuanya mendapatkan kasih sayang dari orang tuanya juga. Kembang mate adalah tanda yang mempunyai sifat sebagai cermin. Anak menjadi cermin orang tua karena sifat orang tua mewujud di dalam diri anak. Dasar hubungan orang tua dan anak adalah hubungan genetik. Oleh karena itu, anak menjadi ikon orang tua sehingga anak menjadi simbol keluarga. Anak adalah tempat melihat diri, adalah tempat bercermin bagi orang tua.

Frasa buaq ate kemudian menjadi symbol yang merujuk pada posisi anak dalam suku Sasak. Selanjutnya frasa kembang mate, secara etimologis kata kembang sendiri bermakna bunga yaitu benda yang disukai orang karena keindahan yang dimiliki. Pada tataran rhema, kembang kemudian dipersepsikan sebagai sesuatu yang membuat hati senang atau tenang. Dalam kultur Sasak sendiri sering didengar ungkapan kembang keluarge yang memiliki padanan makna dengan anak. Karena anak adalah kembang/bunga yang mampu membuat orang tua bahagia. Sehingga selelah apapun orang tua bekerja, ketika melihat anaknya, rasa lelah itu bisa hilang. Atau sekuat apapun orang tua marah pada isterinya jika melihat anaknya maka amarah itu bisa ditunda. Sehingga kata kembang menjadi dicent yang cukup kuat yaitu sebagai penyelemor angen, pembuat rasa bahagia orang tua yang dalam konteks ini adalah anak itu sendiri. Sementara itu kata mate dalam bahasa Indonesia berarti mata yang pada tataran rhema mengacu pada fungsi dan kegunaan yang cukup sentral dalam hidup manusia. Tanpa mata segala bentuk keindahan dunia dan keindahan hidup tidak akan pernah bisa dinikmati. Kata mate sendiri menjadi ikonitas personal orang. Dalam bahasa Sasak juga sering didengar frasa abang mate, batu mate yang secara metaforis mengacu pada prilaku tidak baik seseorang. Oleh sebab itu, kata mate juga menjadi indeksikal seseorang, yaitu keperibadian seseorang bisa dibaca atau diketahui dari sorot matanya. Sehingga mate memiliki posisi yang sama dengan kata kembang yaitu substansial. Klausa buaq ate kembang mate kemudian menjadi sebuah ungkapan tentang posisi urgen seorang anak bagi orang tua Sasak sampaisampai diasosiasikan dengan permata ( $m i$ rah), kembang (bunga), ate (hati) dan mate (mata) yang secara fungsional sangat berarti.

Pada larik ketiga yaitu mulen tulen kubantelin, frasa mulen tulen mengacu pada kesungguhan yang ditunjukkan oleh orang Sasak dalam menjaga dan mensyukuri kehadiran seorang anak dalam keluarga. Selanjutnya kata bantelin merupakan afiksasi dari kata bantel yaitu mengikat/terikat. Kata bantel sendiri dilakukan pada sesuatu yang dianggap penting, bermanfaat, berharga. Kata bantel juga adalah sesuatu yang sudah terikat kuat, ikatan yang kuat, dan harga mati dalam hubungannya dengan buaq ate. Sehingga kata bantel sering ditemukan sinoniminya dalam bahasa Sasak seperti ungkapan bantelne mate, yang bermakna kematiannya terikat atau disebabkan sesuatu yang melekat pada seseorang, entah karena persoalan cinta yang ditolak, sakit hati, maupun yang lainnya. Pada tataran qualisign kata bantelin mengacu pada karakter orang Sasak 
yang selalu menjaga atau mengikat sesuatu yang dianggap berharga. Hal ini kemudian menjadi manifestasi kultural Sasak yang sejalan dengan lomboq (lurus) itu sendiri. Secara umum klausa mulen tulen kubantelin menerangkan bagaimana wujud keseriusan orang Sasak dalam menjaga anaknya (buaq ate kembang mate) sampai-sampai kata kubantelin memperkuat bukti keseriusan itu. Jiwa orang tua dan anak terikat menjadi satu. Jika anaknya sakit, maka sakit pulalah yang dirasakan oleh orang tuanya, begitupun sebaliknya. Dengan demikian, frase Mulan tulen kubantelin ini adalah ungkapan yang dipahami sebagai sebuah sikap bahwa apapun akan dilakukan walau harus mempertaruhkan nyawa demi anak. Sikap itu terlihat di dalam prilaku orang tua. Sikap itu didasari oleh sebuah keyakinan bahwa anak adalah bentuk kepercayaan Tuhan kepada manusia. Oleh karena itu menjaga anak adalah menjaga kepercayaan, menjaga sebuah titipan. Frase itu menjadi ikon pembelaan, karena apapun yang menimpa sang anak harus dibela. Pada dasarnya anak selalu benar. Jika terdapat kesalahan dalam prilaku anak maka kesalahan itu bukanlah kesalahan sang anak, tetapi kesalahan orang tua yang bisa dianggap gagal dalam mendidik. Masyarakat Sasak selalu bertanya tentang anak siapa itu, jika anak tersebut misalnya mempunyai prilaku buruk.

Pada larik sintung jari salon angin, frasa sintung jari sendiri dalam bahasa Indonesia bermakna sekedar menjadi, sedangkan frasa salon angin bermakna sisa rasa. Kata sintung sendiri menjadi ikonitas keikhlasan, pasrah, berserah diri yang dilakukan orang Sasak. Pada fase qualisign pembuat tembang sadar bahwa sekuat apapun ia bantel (ikat) rasa memiiki atau kecintaan terhadap anaknya akan ada masa dimana kerelaan akan dituntut. Dalam hal ini kerelaan melapas anak jika sudah menikah, pergi keluar desa seperti menuntut ilmu atau pergi bekerja ke daerah rantauan. Frasa salon angin kemudian menjadi manifestasi bahwa kecintaan, rasa memiliki yang dipegang teguh oleh orang tua dalam sanubarinya tidaklah hilang seutuhnya ketika anak pergi secara ragawi dari orang tua mereka, akan tetapi akan tetap ada sisa cinta dan rasa memiliki dalam jiwa untuk anaknya sehingga cenderung akan melakukan apapun untuk membantu anaknya menjalani hidup dengan sisa hidup yang dimilikinya. Frasa salon angin pada tataran rhema yaitu harapan. Sehingga salon angin kemudian menjadi satu-satunya penyemangat yang akan dijaga oleh orang tua disebabkan semakin besarnya anak maka semakin kompleks dan banyaknya kemungkinan yang akan terjadi dengannya seperti pergi jauh, menikah, merantau, meninggal, dll. Sehingga, frasa salon angin kemudian menjadi manifestasi harapan, penyemangat orang tua Sasak ketika hal-hal yang sifatnya duniawi datang menghampiri anaknya.

Secara keseluruhan interpretasi pada bait ini yaitu pembuktian karakter orang Sasak yaitu melankoli, kerelaan/keridhoan, rela untuk memiliki dan rela untuk melepas jika sewaktu-waktu sesuatu yang dicintai harus pergi. Frase Sintung jari salon angin juga adalah ungkapan yang berarti pembelaan dan atau pembenaran, karena apapun yang terjadi pada anaknya, orang tua akan membela sampai nafas terakhir. Demi anaklah sisa nafas yang dimiliki orang tua dan hanya untuknya sisa nafas tersebut. Kata angin menjadi ikon dari angen (hati), sehingga salon angi(e)n dalam alam pikir orang Sasak termasuk 
yang menjadi pilihan kata dalam judul teks tersebut adalah angin sekaligus dengan maksud angen (hati).

\section{Dari Ketidakberdayaan ke Penerimaan}

Bait kedua, yaitu Berembe bae side dende, jangke ngene, kembang mate kelepangne isiq angin, laguq temah side dende, bau bedait maliq. Frasa Berembe bae merupakan qualisign terhadap pengejawantahan ketidakberdayaan menghadapi kenyataan. Ungkapan tesebut menjadi sinsign dalam bentuk ketakutan, sesal, bercampur rasa harap menjadi padu. Tidak mudah kemudian mengkombinasikan rasa tersebut, sehingga dibutuhkan pribadi dan jiwa yang kuat untuk bisa mengimani ungkapan itu. Frasa side dende bermakna anda (side), anak (dende). Kata dende (anak) biasanya diacu pada anak perempuan, sedangkan kalau laki-laki disebut (raden). Kata dende sendiri merupakan gelar kebangsawanan suku Sasak yang paling tinggi. Di depan nama bangsawan lakilaki memakai nama raden dan di depan nama bangsawan perempuan memakai nama denda (Alaini, 2015: 116). Alaini (2015: 116) juga menyebutkan nama gelar lain dalam nama bangsawan, yaitu lalu dan baiq. Penggunaan nama itu mempunyai kadar kebangsawanan lebih rendah dibandingkan dengan raden dan denda.

Pada tataran rhema kata dende menjadi pujian yang diberikan oleh orang tua Sasak kepada anaknya, meskipun sang anak tidak bergelar dende. Pada tataran sinsign orang tua Sasak sering memanggil anaknya dengan sebutan dende, kembeqne dende, araq ape dende, napi dende, merupakan contoh panggilan yang digunakan orang tua kepada anaknya sebagai tanda pujian, sayang dan cinta yang tinggi seperti tingginya status dende tersebut dalam strata sosial suku Sasak. Digunakannya kata denda dalam bait tersebut menunjukkan bahwa orang Sasak yang dimaksudkan adalah bangsawan. Dende menjadi simbol Sasak. Dengan demikian, orang Sasak yang dikomunikasikan oleh teks itu adalah orang bangsawan kawula. Frasa jangke ngene bermakna sampai begini, pada tataran dicent frasa jangke ngene menjadi bukti keresahan, sesal dan harap sudah tidak bisa lagi dipendam karena sintung jari salon angin itu sendiri. Jangke ngene juga merupakan simbolisasi ketakkuasaan orang Sasak pada sesuatu yang bukan menjadi miliknya secara dzat. Secara menyeluruh pada larik ini mengindikasikan rasa takut kehilangan sekaligus bentuk penerimaan atas apapun yang menimpanya.

Pada larik kedua yaitu kembang mate kelepangne isiq angin dapat dipahami dalam dua pengertian. Pertama, Frasa kembang mate, secara etimologis kata kembang sendiri bermakna bunga yaitu tumbuhan yang disukai orang karena keindahan yang dimiliki. Pada tataran rhema, kembang kemudian dipersepsi sebagai sesuatu yang membuat hati senang atau tenang. Dalam kultur Sasak sendiri sering didengar ungkapan kembang keluarge (bunga keluarga) yang memiliki padanan makna dengan anak. Karena anak adalah kembang/bunga yang mampu membuat orang tua bahagia. Sehingga selelah apapun orang tua bekerja, ketika melihat anaknya, rasa lelah itu bisa hilang. Atau sekuat apapun orang tua marah pada isterinya jika melihat anaknya maka amarah itu bisa ditunda. Sehingga kata kembang menjadi dicent yang cukup kuat yaitu sebagai penyelemor angen, pembuat rasa bahagia orang tua yang dalam konteks ini adalah anak itu sendiri. Sementara itu kata mate dalam bahasa Indonesia berarti 
mati. Pada tataran rhema mengacu pada ketiadaan identitas, atau pudarnya kekhasan pribadi luhur orang Sasak. Sehingga kualitas tanda yang tampak yaitu orang Sasak merasa ketakutan dengan semakin terpuruknya pemahaman dan kecintaan orang Sasak akan kultur dan nilai filosofi adatnya. Pada tataran sinsign kata mate mengacu pada semua yang hidup dan diciptakan dalam kehidupan tidak ada yang abadi, semua akan kembali kepada pemilik diri. Oleh sebab itu frasa kembang mate menjadi simbolitas pudarnya nilainilai luhur, cinta, harapan, dan kejujuran yang selama ini disematkan dan menjadi identitas Sasak. jika anak adalah harapan maka pudarlah harapan ketika sang anak sudah dibawa arus peradaban, kelepang siq angin. Kedua, kembang mate adalah metafor untuk anak. Kembang mate mengandung pengertian cermin orang tua. Dikatakan demikian karena orang tua melihat dirinya sendiri ketika melihat anaknya. Kata mate dalam pengertian yang kedua adalah mata. Kembang yang mati (mate) dan kembang mate (cermin orang tua) menunjukkan kondisi terbawa oleh angin (kelepangne isiq angin). Selanjutnya frasa kelepangne isiq angin bermakna diterbangkan atau terbawa oleh angin. Dalam pengertian yang pertama, kembang mate mengacu pada konsep hidup dalam mati oleh karena itu dibawa oleh angin kehidupan, oleh peradaban. Pada tataran rhema frasa ini bermakna kehilangan dan ketiadaan diri. Kehilangan yang dimaksud adalah kehilangan identitas itu sendiri, kehilangan buaq ate kembang mate yang selama ini dipuja dan dijunjung tinggi oleh orang tua Sasak. Angin dalam frase kelepangna isiq angin menjadi simbol peradaban. Dunia tardisi dan cara pandangnya terbawa oleh oleh arus atau angin modernitas (Budiwanti, 2000). Orang-orang sasak banyak yang memilih pergi dari asalnya untuk mangadu nasib ke negara lain (Lindquist, 2010), sedangkan yang tidak pergi tetap diam dengan cara pandang baru yang disebut modernitas. Seni musik tradisi sudah bercampur dengan seni modern, misalnya musik kecimol (Yudarta \& Pasek, 2017: 317). Semua itu terjadi pada semua ruang baik pada levelperkawinan, rumah tangga sampai pada level kenegaraan dalam konteks kesadaran berbangsa orang Sasak. Pada tataran indeksikal frasa tersebut menggambarkan bahwa tidak ada keabadian di dunia ini. Selanjutnya pada tataran dicent frasa tersebut menjadi bukti nyata bahwa saat ini apa yang sudah menjadi tradisi leluhur, yang dikeramatkan, didewakan karena dianggap sebagai bagian dari jalan hidup berangsur-angsur menghilang. Apalagi hegemoni media dan arus budaya luar yang setiap hari merasuki alam bawah sadar generasi Sasak sehingga perlahan tapi pasti mereka meninggalkan semua ajaran dan falsafah hidup yang sudah menjadi pakem leluhur gumi Sasak. Sementara itu pada tataran qualisign frasa di atas menjadi jeritan hati yang cukup mendalam bagi orang tua Sasak atas fenomena kekinian yang menggerogoti generasinya. Tidak ada yang bisa dilakukan kecuali menjadikan itu sebagai bantel angen, sintung jari salon angen, hanya sekedar menjadi sisa rasa, sisa harapan, sisa impian yang dibanggakan.

Baris selanjutnya yaitu laguq temah side dende yang bermakna tapi bagaimana lagi anakku. Klausa ini menjadi ikonitas kerelaan orang Sasak yang selalu berpikiran posistif atas sikap atau tindakan yang sejatinya melukai perasaannya. Pada tataran qualisign dimaknai bahwa suku Sasak 
khususnya orang tua Sasak selalu optimistik di tengah keterpurukan yang mengancam mereka. Nilai optimistik inilah kemudian menjadikan peribadi Sasak menjadi peribadi yang tangguh dan kuat dengan beragam persoalan. Sementara itu pada tataran sinsign menunjukkan bahwa beberapa kali Sasak dikuasai oleh pihak luar, namun tetap saja merunduk, mengambil hikmah setiap kejadian dan optimis bahwa hari esok akan lebih baik. Bahkan sampai saat ini kita melihat pola ini masih menghinggapi kehidupan orang Sasak, menjadi buruh di rumah sendiri namun mereka tetap saja menerima dan yakin bahwa akan ada hari baik esoknya. Sehingga ungkapan sehari-hari seperti ape yak te uni, mule ye wah aneh (memang begitulah), menjadi bukti nyata bahwa kerelaan dan optimistis selalu ada dalam sanubari orang Sasak. Dengan demikian, frase laguq temah adalah tanda yang menunjukkan penerimaan takdir bahwa segala sesuatu yang terjadi dalam kehidupan sudah digariskan tuhan. Apapun yang terjadi dan dialaminya adalah sesuatu yang memang sudah ditentukan tuhan yang menjadi nasibnya ketika melaksanakan hidup di dunia. Artinya, semua yang terjadi tersebut adalah pemberian tuhan yang semuanya tampil nyata dalam bentuk peristiwa, baik yang sifatnya baik maupun yang tidak baik. Hal itu terjadi juga dalam cerita rakyat Sasak seperti Putri Mandalika, Dewi Rengganis, dan Dende Cilinaye.

Baris terakhir yaitu bau bedait malik bermakna semoga bisa bertemu kembali dan menunjukkan bahwa apapun yang terjadi pada sang anak yang terpenting adalah masih bisa bertemu lagi (bedait malik) walau dalam keadaan mengaharukan. Pertemuan itu terjadi dalam kondisi berserah diri bahwa tidak ada daya upaya untuk meng- hindari takdir. Tetapi yang paling penting adalah orang tua dan anak masih bisa bertemu, menyatu. Pertemuan keduanya disebabkan oleh kerinduan penyatuan akan asal dan tujuan, antara yang diberi kasih sayang dan yang menerima kasih sayang. Pada tataran rhema frasa ini bermakna harapan, peluang. Harapan agar tidak lagi terbawa arus kehidupan (kelepangne isiq angin) tidak terjadi lagi. Pada tataran qualisign mengacu pada keyakinan yang kuat akan keajaiban pada hari esok. Keyakinan akan segala yang pergi akan digantikan dengan yang lebih baik. Keyakinan akan kepergian buaq ate kembang mate, kelepangne isiq angin pasti dipertemukan kembali. Sementara itu pada tataran rhema frasa di atas menujukkan bahwa orang Sasak tidak pantang menyerah, tidak pernah putus asa atas segala sesuatu yang menimpanya karena segala sesuatu yang terjadi sudah ada ketentuan dari pemilik kehidupan. Sehingga membumikan semangat pantang putus asa dan selalu menerima takdir dengan selalu optimis akan sebuah keadaan yang lebih baik adalah salah satu cara untuk tetap bisa bertahan menjalani hidup dalam kolonialisme yang berkepanjangan, bertahan menjaga norma dan nilai diri yang semakin memudar dan bercampur dengan yang lain.

\section{Kabar Kesedihan Bangsawan Sasak}

Pembacaan semiotik tersebut di atas mengantarkan pada pemaknaan teks ke dalam konteks yang lebih luas. Orang Sasak yang mana yang direpresentasikan oleh teks tersebut. Melalui pembacaan semiotik tersebut dapat diketahui representasi Sasak yang mana yang ditunjukkan oleh teks angin alus. Secara keseluruhan teks angin alus sebagai sebuah tanda mengacu kepada 
masyarakat Sasak kelas bangsawan-kawula. Penggunakan istilah mas mirah dan denda, dan dengan demikian orang tua Sasak yang dimaksudkan, yang merasa kehilangan dan merasakan luka tersebut adalah kelas bangsawan kawula. Dalam konteks masa kini, perasaan itu dialami juga oleh perwanga dengan jamaq. Oleh karena itu, representasi Sasak-Lombok dalam teks angin alus adalah representasi bangsawan kawula. Representasi Sasak dalam teks rersebut dapat dikatakan representasi "yang lain." Teks angin alus adalah representasi diri Sasak yang lain (other), yang berbeda dari self. Interpretasi terhadap teks angin alus ini adalah upaya mengungkap atau melestarikan makna yang tersebunyi di dalam teks tersebut. penafsiran tersebut muncul sebagai bentuk refleksi peneliti sebagai orang Sasak yang sampai saat ini masih menemukan kenyataan bahwa para bangsawan Sasak merasa diri sebagai manusia asli Sasak yang paling tahu siapa Sasak sebenarnya dan seperti apa budayanya. Teks angin alus masih ada dan terus ada untuk mengabarkan tentang berita kesedihan yang dialami oleh generasi penerus Sasak. Dalam konteks sekarang, dan dalam interpretasi masa kini, para bangsawan tersebut mengalami kesulitan untuk bertahan hidup dengan gelar kebangsawananya ketika dunia modern lebih membutuhkan gelar akademik dalam mencari pekerjaan. Mereka, para generasi bangsawan, memilih merantau ke negeri orang daripada menjadi buruh di negeri sendiri. Interpretasi peneliti yang dikemukakan di atas adalah usaha menggapai makna tersirat yang tidak dimaksudkan oleh pengarangnya, karena dunia ketika teks dibuat jauh berbeda dengan ketika sekarang teks tersebut diproduksi ulang dengan media yang berbeda. Konteks yang berbeda mem- buatnya terbuka untuk diinterpretasi.

Dengan pembacaan semiotik di atas, struktur teks menunjukkan bahwa masyarakat Sasak kelas bangsawan kawula merasakan sedih dan luka. Penderitaan tersebut disebabkan oleh arus kehidupan atau peradaban. Dunia teks tersebut ditunjukkan oleh baris mulan tulen kubantelin, sintung jari salon angin, berembe bae, kelepangna isiq angin, laguk temah. Teks tersebut mengabarkan kesedihan orang Sasak bangsawankawula. Dalam konteks masa kini, banyak bangsawan yang masih bangga dengan gelar kebangsawanannya. Sedikit di antara mereka yang mampu mempertahankan kekayaannya seperti tanah. Pada zaman kolonial, mereka menempati posisi penting dalam pemerintahan. Mereka memiliki banyak tanah dan menjadi tuan tanah. Namun, ketika Indonesia merdeka ia masih bertahan di bawah pemimpin Jawa. Ketika pemimpin daerah mulai diambil alih oleh putra daerah, oleh Sasak yang diasumsikan asli, mereka mulai kesulitan bertahan. Banyak di antara bangsawan menjual tanah dan hidup sederhana. Mereka sulit meraih posisi dengan mengandalkan gelar bangsawan. Sekitar tahun 2000-an, banyak di antara mereka memilih merantau keluar negeri menjadi tenaga kerja. Perempuan bangsawan mulai kesulitan menemukan jodoh yang sesama bangsawan. Ketika perempuan bangsawan menikah dengan lakilaki perwangsa dengan jamaq atau jajar karang, mereka dibuang atau tidak dianggap lagi sebagai anak. Mereka masih memegang teguh adat walau harus melepaskan anaknya, membuang anaknya. Pada akhirnya seiring waktu, sang anak akan diterima kembali, bertemu (bedait), menyatu kembali sebagai keluarga dalam suasana yang berbeda, suasana sedih. Bangsawan yang ber- 
tahan dengan adat sepenuhnya tidak menerima anaknya kembali. Bangsawan yang sudah pernah mengenyam pendidikan tinggi lebih terbuka menyikapi adat. Dunia yang ditawarkan teks tersebut tersebut membuat peneliti sadar bahwa sebagai seorang anak, terlepas dari apakah bangsawan atau perwangsa dengan jamaq, harus siap menerima takdir sekalipun sesuatu yang menimpanya tidak diharapkannya, namun bukan berarti tanpa bisa diubah. Frase bau bedait malik dalam teks tersebut menunjukkan kemungkinan untuk mengubah sesuatu yang sudah terjadi itu menjadi sesuatu yang diharapkan atau dicitakan. Namun, semuanya tergantung pada seberapa kuat keyakinan kita untuk mengubahnya. Konsep bau bedait adalah upaya memperbaiki apa yang sudah terjadi atau kita lakukan, baik yang berupa kesalahan maupun kecerobohan.

\section{SIMPULAN}

Berdasarkan hasil dan pembahasan dapat disimpulkan hal-hal berikut. Pertama, dunia teks yang digelar teks angin alus adalah dunia tragik, kabar luka dan kesedihan. Luka dan kesedihan akibat denda (sang anak) yang merupakan cermin dirinya (buaq ate kembang mate), permata hati (mas mirah) terbawa arus kehidupan dan peradaban. Kabar itu memposisikan anak sebagai sebuah kebenaran dan sebagai harga diri.

Kedua, kabar ketidakberdayaan dan penerimaan atas arus peradaban (modernisme) yang membawanya ke dalam dunia baru yang berbeda dengan dunia tradisi. Ketiga, rasa kehilangan dan kesedihan tersebut dialami oleh masyarakat Sasak kelas Bangsawan. Dengan demikian, teks angin alus merepresentasikan kehilangan dan kesedihan masyarakat Sasak kelas bangsawan. Namun, tidak dapat diingkat para bangsawan Sasak tersebut sudah belomboq atau meLombok. Bangsawan menjadi simbol Jawa yang meLombok. Bangsawan dalam teks itu direpresentasikan sebagai orang yang siap menerima takdir dan merindukan penyatuan kembali antara orang tua dan anak, antara asal dan tujuan. Kenyataan tersebut membuat peneliti sadar bahwa cara pandang Sasak dan makna diri sebagai orang Sasak tidaklah tunggal, namun beragam. Beragamnya pandangan tersebut menunjukkan bahwa masyarakat Sasak mengalami percampuran dengan pihak luar.

\section{UCAPAN TERIMA KASIH}

Ucapan terima kasih disampaikan kepada teman sejawat yang telah memberi masukan dalam proses penelitian. Ucapan terima kasih disampaikan juga kepada reviewer yang telah memberi masukan untuk perbaikan artikel ini.

\section{DAFTAR PUSTAKA}

Alaini, Nining Nur. 2015. Stratifikasi Sosial Masyarakat Sasak dalam Novel Ketika Cinta Tak Mau Pergi Karya Nadhira Khalid, Jurnal Kandai, Volume 11 Nomor 1, hlm 110-123

Budiwanti, Erni. 2000. Islam Sasak: Islam Wetu Telu versus Islam Wetu Lima. Yogyakarta: Lkis.

Fajri, Muhammad. 2015. Mentalitas dan Ideologi dalam Tradisi Historiografi SasakLombok abad XIX-XX. UGM. Disertasi Ilmu Sejarah.

Faruk. 2012. Metode Penelitian Sastra: Sebuah Penjelajahan Awal. Yogyakarta: Pustaka Pelajar.

Fauzan, Ahmad. 2013. Mitologi Asal-Usul 
Orang Sasak (Analisis Struktural pemikiran orang Sasak dalam Tembang Doyan Neda). UGM. Tesis Antropologi.

Hagerdal, H. (2016). Expansion in the Shadow of the Company. Bijdragen tot de Taal-, Land- en De Volkenkunde, 172 (2/3), pp 279-309.

Haryatmoko. 2015. Membongkat Rezim Kepastian, Pemikiran Kritis Post-Strukturalis. Yogyakarta: Beokoe Tjap Petroek.

Jamaludin. 2011. Sejarah Sosial Islam di Lombok tahun 1740-1935. Jakarta: Kementrian Agama.

Kingsley, Jeremy. 2011. Pelopor Perdamaian atau Perusak Perdamaian?: Pemilihan Kapala Daerah, Kepemimpinan Agama, dan Proses Perdamaian di Lombok, Indonesia, dalam Kegalauan Identitas: Agama, Etnisitas, dan Kewarganegaraan pada masa PascaOrdebaru. Jakarta: Gramedia.

Lindquist, Johan. 2010. Labour Recruitment, Circuit of Capital and Gendered Mobility: Reconceptualizing the Indoesian Migration Industry. Pacific Affair, Volume 83 Nomor 1, hlm 115-132
Noth, Winfried. 1995. Handbook of Semiotik. Abd. Syukur Ibrahim (ed.). 2006. Surabaya: Universitas Airlangga.

Nuriadi. 2014. Mendefinisikan Orang Sasak melalui Habitusnya: "Pelagaq Lekong Belah," dalam Prosiding Kongres Bahasa Daerah NTB, hal 227-242.

Trisnawati, Ida Ayu dkk. 2016. Strands of Gumi Sasak Pearl: Harmoni-based Tourism Product in Mataram City, West Nuda Tenggara Barat, dalam Mudra Journal of Art dan Culture Volume 31 Nomor 3, hlm 29 5-307.

Usup. 2011. Citra Pluralitas dan Religisitas Masyarakat Sasak di Lombok: Tinjauan Sosio-semiotik atas Ta Melak Mangan. Universitas Gajah Mada: Yogyakarta. Tesis.

Yudarta, I Gede \& Pasek, I Nyoman. (2017). Kecimol Music as Cultral Idetification of Sasak Ethnic, dalam Mudra Journal of Art and Culture, Vol 32 Nomor 3, hlm 314-318

Yudarta, I Gede. 2016. Potensi Seni Pertunjukan Bali sebagai Penunjang Pariwisata di Kota Mataram, Nusa Tenggara Barat, dalam Mudra Vol. 31 No. 1, hlm 37-53. 